\title{
（3）寝台移動法について In Case of the Moving Couch Method
}

全身照射に電子加速器を用いている施設が大部分であることから、寝台移動法において技術的にも っとも問題となるのは、線量率の変動である。しかしこれは、加速器のモニター線量計の信号をつィ ードバックさせ、M U / c m との乗算を演算回路で行なって寝台駆動モーターを制御することにより 解決できる。この線量率対応速度变換方式の導入によって初めて、葠台位置に対応させた M U / c m を P C に入力し、結果として任意の移動区間ごとに線量を変える区間対応速度変換方式が可能になる のである。

寝台移動法で次に問題なのは遮蔽である。ブロックの厚さや照射野の大きさによって、ブロック辺 縁の遮蔽効率やブロック周辺の線量減少の程度が異なる。このことだけから言えば、スリット状に狭 い照射野ほど良いことになるが、照射野の大きさは平坦度や照射時間にも影響があるので、おのずと 適当な大きさが定まってくる。

照射中には線量率や移動寝台の位置をモ二ターで監視することが必要である。そして照射後には、 実際に照射した装置側の状態、すなわち一照射ごとの照射量・時間・寝台位置等を記録することが必 要である。これによって、計画通り照射されたことを確認できる。

寝台移動法の場合は、治療線量モニターとしての透過線量計の適用が容易ではなく、特別に工夫さ れた線量計の開発が必要なため、ファントムによる測定結果を治療にあてはめる方法が実際的であろ う。そのために、線量率対応速度変換方式と記録確認は一層重要になる。寝台移動法を採用し、それ がルチーン化されるまでの初期の段階では、電離箱や T L D などを使って他の方法で確認しておく必 要があることはもちろんである。

1982 年以来、 100 例以上に寝台移動法を適用してきた。この間に 3 台の寝台を作った経験か ら、それらの改良経過についてもふれる。

\section{（4）ムービングビーム全身照射法および電子線全身照射法 Total Body Irradiation with a Moving Beam Technique and with Multi Field Technique by Electron Beam.}

東京女子医科大学病院 菊地 峻

骨髄移植の前処置として行う全身照射法（TＢＩ）は、AAPM report に報告されているように多く の方法があり、それぞれの施設に合った方法により、実施しているのが現状である。

狭い照射室で適用できる方法のーつとして、既設の照射装置( NELAC-1018) のハード面の改造なし に、制御機構のソフト改造により、ムービングビームによる全身照射法を開発した。

S T Dを180 cmとし、患者の体軸方向に沿って架台を120 度回転させ、架台回転ごとのcount/degree の制御又は、照射野長を変化させ、ビームプロファイル補正するプログラムにより、成人を対象 として平坦なプロファイルを得る方法である。

ファントムにより基礎的測定と計算により組み立てたムービングビーム照射法は、T B I の一照射 法として適用できる。当施設では、昭和6 1 年 1 月より実施している。

(1)ム-ビングビーム照射の概要(2)照射条件と設定(3)肺補償フィルタ取り付什位置とビームプロファイ ル(4)害照射時の線量モニ夕法(5)患者体型に沿ったビームプロファイルの検討(6)本照射法の精度、等に ついて述べる。

電子線については、症例数は多くはないが、主な対象は、mycosis-fungoides であり、一般的に行 われている照射法を紹介し、特に照射室が狭い施設でも実施できる、継ぎ目照射について述べる。

(1)継ぎ目におけるビームプロファイルの検討。(2)最適エネルギ一。(3)梁在性typeにおろけboost 治 療。(4)投与線量。(5) X線のcontamination 。(6)水晶体、口粘膜の防護。等につき検討を行い、報告す る。 